\title{
4 Victory celebration and the unmaking of diversity in post-war Sri Lanka
}

\author{
Paikiasothy Saravanamuttu
}

Eleven years after the military defeat of the Liberation Tigers of Tamil Eelam (LTTE or Tamil Tigers), the movement towards transitional justice in Sri Lanka has been, at best, minimal. An Office of Missing Persons and an Office for Reparations have been established, largely as a consequence of international pressure. However, the narrative, in the main, has been one of continued militarization of the civilian space and the shrinking of space for civil society activity, the appointment of past and serving military officers in key civilian positions, the acquisition of land in the minority provinces of the north and east and the continued use of the Prevention of Terrorism legislation (Human Rights Watch 2021; Office of the UN High Commissioner for Human Rights 2021; Centre for Policy Alternatives 2021). Sri Lanka continues to be in a post-war situation in which the guns have fallen silent, rather than in a postconflict situation in which the sources of conflict are no longer sustained and reproduced. With the opening up of a new Sinhala-Muslim fault line, the complex roots of conflict are being further nurtured and sustained.

What lies at the heart of the seeming intractability of conflict and the daunting challenge of conflict transformation in Sri Lanka? The argument has been advanced that one of the key outcomes of the government of Sri Lanka's military victory over the Tamil Tigers in the almost 30-year-long civil war that ended in 2009 is the triumphalist assertion of the ethno-religious political identity of the majority Sinhala community (Fernando 2013; Peiris 2018; Governeur 2010). In this chapter, I will argue that while this happened, the assertion of this majority identity of Sinhala Buddhism has not been discovered or invented on the heels of the military victory in 2009, but it has been nurtured over a longer period. It has progressively come to reside at the very heart of the majority community's self-perception and, consequently, it has become a key contributor to conflict and the sustenance thereof.

\section{The triumphalist moment}

The almost 30-year-long civil war came to an end in May 2009 with the military victory of the Sri Lankan armed forces over the LTTE. However, at this point, even the government maintained that the victory was a military

DOI: $10.4324 / 9781003167280-5$ 
one and not a conclusive end to the ethnic conflict, which was a political issue warranting a political settlement. Therefore, in May 2009, when the guns fell silent, Sri Lanka did pass into a post-war phase but not a postconflict situation in which the roots of conflict could have been addressed and overcome.

Irritated by frequent accusations of wartime human rights violations and war crimes, the Rajapakse government adopted a triumphalist and assertive role, both internationally and domestically. It was eager to present Sri Lanka as one of the few countries, perhaps the only one - and what is more, a country from the global South - to have defeated terrorism. Back at home the government defined for itself the role of the defender of national sovereignty, security and territorial integrity, and the defender of all those who were involved in the defeat of the LTTE.

The news that the LLTE had been defeated was greeted with an outpouring of relief and celebration in the south of the country where the Sinhalese form the majority, with festive milk rice being served on the streets and fireworks set off. Annual independence celebrations in the wake of the defeat of the LTTE prominently include a march featuring the military technology and hardware that were procured in order to win the war, as well as the singing of the national anthem in Sinhala. ${ }^{1}$ Both major political parties - the Sri Lanka Freedom Party (SLFP) and its allies, as well as the rival United National Party (UNP) and theirs - shared in the main the position that no one was going before any tribunal or court to face charges of war crimes. Politicians from both sides vied with each other to proclaim their nationalist credentials and offered to face any tribunal themselves on behalf of the members of the security forces (International Crisis Group 2017).

There were attempts by the Mahinda Rajapaksa regime to consider the initiation of a truth and reconciliation commission and discussions were held with the South African government about how and why it should be established. The South African President Jacob Zuma appointed his deputy, Cyril Ramaphosa (now president of South Africa), as Special Envoy to Sri Lanka. Ramaphosa visited Colombo in July 2014 and met with government leaders and the Tamil National Alliance, but to no avail. The (hesitant) Sri Lankan interest in the South African Truth and Reconciliation Commission (TRC) might have been motivated by the TRC's approach to amnesty, as the Sri Lankan government sought to emphasize restorative justice rather than retributive justice (Jayasuriya 2014; Anketell 2013) Perhaps there was a misunderstanding of the South African process: in effect, the TRC had granted amnesty only to 849 out of 7,112 applications, after full confession and testimonies by both the perpetrators and the victims (Anketell 2013). The South African position with regard to Sri Lanka was that the TRC could not be cherry-picked from a series of recommendable measures for a political settlement and reconciliation.

While ethno-religious nationalist fervour gained salience, the political opposition of the UNP, its allies and sections of civil society were painted as 
being on the wrong side of the patriot/traitor divide and beholden to Western politicians, who were assumed, in turn, to depend on the Tamil diaspora for votes in their respective countries. In addition, the argument was made that the West was envious of Sri Lanka for defeating terrorism. Even as it maintained this position, the Rajapaksa regime could not, however, ignore international opinion and responded in 2010 with the establishment of the Lessons Learned and Reconciliation Commission (LLRC) (Groundviews 2011). However, the tardy implementation of its recommendations formed the basis of the first US-sponsored resolution on Sri Lanka at the Genevabased United Nations Human Rights Council (UNHRC) in 2012. From then on, the UNHRC, where several US-sponsored resolutions on Sri Lanka were presented during the 2012-14 sessions, became the site of increasing international contestation. The regime was not able to muster the majority it did in 2009 to see off a critical resolution in the following years, except when it co-sponsored the resolution in 2015. Opposition to it in Geneva gave the Rajapaksa regime the grounds for renewing the claim that Sri Lanka was being besieged internationally and therefore had to close ranks nationally.

\section{A short window for transitional justice}

By passing an 18th Amendment to the Constitution, Mahinda Rajapaksa removed the two-term limit on the presidency, thereby allowing him to contest an unprecedented third term in 2015. The opposition parties settled on Maithripala Sirisena, the Minister of Health and General Secretary of the SLFP, as their joint candidate. Sirisena had unimpeachable Sinhala Buddhist credentials and could bank on the votes of the minorities as well. Ranil Wickremasinghe, the UNP leader and Leader of the Opposition, was held to be too urban and insufficiently nationalist to hold a candle to Rajapaksa, despite allegations of corruption and nepotism against Rajapaksa and his family. The political space in this respect was bounded by the key requirement of the dominant ideology of the day - that the candidate had have strong Sinhala Buddhist credentials.

Siresena defeated Rajapaksa in January 2015 and appointed Wickremasinghe as his prime minister. Rajapaksa, however, still garnered a considerable number of votes from the majority Sinhala Buddhist community. From the outset, the differences in ideology, background and approach to governance between Siresena and Wickremasinghe made for an unstable and indecisive government. This, along with Rajapaksa's hold on the majority community vote base, facilitated his re-entry into parliament in the general election that followed in August of that year along with the founding of a new party, the SLPP, under his leadership.

The Yahapalanaya (Good Governance) government that was in power from January 2015 to November 2019 nevertheless marked a relative exception from the assertive Sinhala Buddhism promoted by the state. The Sirisena-Wickremesinghe government opened up a front for transitional justice 


\section{4}

Paikiasothy Saravanamuttu

and made a commitment to it at the UNHRC in late September 2015. The Minister of Foreign Affairs, Mangala Samaraweera, proposed to the Council that the Sri Lankan government would establish four mechanisms of transitional justice, namely the Office for Missing Persons, the Office for Reparations, the Truth, Justice and Reconciliation Commission and an accountability commission headed by a special prosecutor, which would include the proactive participation of foreign judges. The latter proposal was met with a storm of protests about national sovereignty and of turning war heroes into war criminals. It gave the Rajapaksas in opposition the argument that they were the only political actors both willing and capable of defending the national interest - defined, yet again, in relation to the interests of the majority community.

In 2016, the government did, however, establish a Consultative Task Force (CTF), composed entirely of civil society representatives, to ascertain the views of the public on transitional justice and the four mechanisms it proposed for its achievement. The CTF asked the government first to address the people, share its vision of transitional justice and reconciliation and explain why it was proposing these four mechanisms. The CTF did in fact draft a speech for the president along these lines but it was never delivered, perhaps because of the political environment of populist nationalism that was prevalent at the time.

As part of the consultative process, the CTF sought to speak to key stakeholders and their representatives. However, attempts to consult the All Ceylon Buddhist Congress were unsuccessful, although a number of monks attended sessions of the CTF at the local level and spoke in particular about the fate of hundreds of monks during the Janatha Vimukthi Peramuna (People's Liberation Front) insurgencies that took place in the south of the country in 1971 and 1988-90. Others were sympathetic to those who sought to disrupt the activities of the CTF, fearing that it would disregard the concerns of the Sinhala Buddhists and report back with preconceived recommendations, or projected that going before the CTF was a waste of time and energy.

The CTF eventually produced a 900-page report and over 45 recommendations, in general and for each of the four mechanisms proposed. The final report of the CTF was to be presented to President Sirisena, but this did not happen and he did not attend the planned handover event. In its recommendations based on consultations with the public - some 7,500 submissions were received in all - the CTF recommended the development of an accountability mechanism with at least one international judge sitting on the bench, on account of the lack of trust and confidence in the Sri Lankan judicial system. This was in conformity with Resolution 30/1 at the UNHRC, which the Sri Lankan government co-sponsored. This recommendation was picked out from among the 40 or so recommendations of the report and rejected. Despite co-sponsoring the resolution in Geneva, the president and prime minister, alongside other leading Sri Lankan politicians, were quick to 
make the point that no member of the armed forces would go before a court or tribunal with foreign judges. This would be a blatant violation of Sri Lanka's sovereignty and national interest. Populist majoritarianism triumphed. However, the Office of Missing Persons was established, as well as, subsequently, an Office for Reparations.

In the 2018 local government elections, the SLPP swept to power in the Sinhala-dominated south. Following the Easter Sunday attacks on churches and luxury hotels by an Islamic group in April 2019, and the government's mishandling of the crisis, the coalition rapidly lost popular support. As the SirisenaWickremasinghe government had restored the two-term limit on the presidency, Mahinda Rajapaksa could not run for office although he was arguably the most popular politician in the country, with political support accruing to him from the disunity and indecisiveness of the Yahapalanaya government. Gotabaya Rajapaksa, former Defence Secretary, brother of Mahinda Rajapakse and a key architect of the victory against the LTTE, was the SLPP presidential candidate in the election of November 2019, which he won with $52 \%$ of the vote. A general election followed in August 2020, in the context of the coronavirus disease (COVID-19) pandemic. The SLPP coalition secured a two-thirds' majority in parliament, dealing a final blow to the country's short-lived experience of considering transitional justice as a societal project.

\section{New fault lines opening up: the Sinhala Buddhist-Muslim conflict}

Apart from the massacre of Buddhist monks in Aranthalawa in 1987 and the attack on the Dalada Maligawa (Temple of the Tooth) in 1998, aimed at severely disrupting the 50th anniversary celebrations of independence, the war between the Sri Lankan state and the LTTE did not have an explicit religious dimension to it. Most Sinhalese and Tamils are pantheists and Sri Lankan Buddhist temples typically accord a place of veneration to Hindu gods.

During the post-war period, however, another site of conflict opened up, this time between the majority Sinhala Buddhist and Muslim communities. This is encapsulated by the rise of the Bodu Bala Sena (BBS - Buddhist Power Force) and its leader, the Venerable Galabodaaththe Gnanasara, and the apparent sponsorship of the BBS by the Rajapaksa regime and the Defence Secretary, Gotabaya Rajapaksa. The impunity afforded to the BBS, despite laws such as the Prevention of Terrorism Act, the Penal Code and the International Covenant on Civil and Political Rights Act available for indictments in respect of hate speech and the incitement to violence, indicate the regime's belief in the notion of Sri Lanka as primarily a Sinhala Buddhist country (Centre for Policy Alternatives 2015, 2018; Wickremesinhe and Hattotuwa 2016). The idea of "unity in diversity" - of the country being made up of a variety of communities different in their own way but wedded to being integral to Sri Lanka - in fact a combination of autonomy and interdependence, was abandoned by state officials. Indicative of this stance is 
that, in September 2014, notwithstanding violence perpetrated against Muslims in Colombo, along the southern coast in Aluthgama and in the Central Province - and despite protests against this violence - the Rajapaksa regime allowed the BBS to invite the incendiary monk Ashin Wirathu from Myanmar to its convention in Colombo (South China Morning Post 2014; Srilal 2014; Schonthal and Walton 2016).

This anti-Muslim sentiment was exacerbated by the Easter Sunday bomb attacks carried out by Muslim extremists, which cost over 250 lives. Simmering tensions were blatantly manifested in the propaganda about Muslim birth rates, halal certification of meat and other products, the reform of the Muslim Marriages and Divorce Act and, most importantly after the Easter Sunday carnage, the issue of wearing the hijab. Although the Easter Sunday bombings were the work of a relatively small number of extremists and the incompetence of the government of the day to act despite having been given clear prior warning and evidence, the issue soon turned into an investigation into the lifestyles and cultural practices of the entire Muslim community. A fast to death by one monk, who had been a member of parliament, was halted when the demand that Muslim ministers resign from the government was met. Attempts by the opposition to keep alive the argument of unity in diversity were grossly inadequate and insufficient, in a context in which the notion of "One Sri Lanka", united and undivided, was given overarching prominence. That "One Sri Lanka" was defined, of course, according to the terms and narrative of the majority Sinhala community.

During the COVID-19 pandemic the issue of the burial or cremation of those who died from the virus arose and caused considerable concern within the Muslim community. Up until March 2021, Sri Lanka did not permit the burial of those who had died as a result of COVID-19 on the grounds that this practice could affect groundwater levels and spread the virus. This stance was contrary to World Health Organization guidelines and flew in the face of local and international scientific opinion. The UN and other international actors called upon the Sri Lankan government to reconsider its position. Governmental committees were set up to resolve the issue and at the time of writing, even though burial was permitted, controversy remained over the location of such burials, leaving the Muslim community convinced that it was being targeted and discriminated against yet again.

\section{The politics of commemoration}

As liberal influences within Sri Lankan politics have waned, Buddhism and the Sangha (priesthood) has gained in salience as legitimizing and galvanizing agents of political affirmation and protest. Consequently, from the belief that those in possession of the Sacred Tooth Relic of the Lord Buddha should rule the country, each decade has seen the further legitimization of Buddhism. This includes the Sangha's participation in the Pancha Balavegaya (Five Great Forces) of the indigenous teachers, farmers, ayurvedic 
doctors, workers and monks that led to the victory of these forces espousing "Sinhala Only" as the official language in 1956, and the monthly calendar based on the full moon (which has significance in Buddhist texts), under which all full moon days were made public holidays in the 1960 s by the Dudley Senanayake government. It also includes taking the presidential oath of office in the Padirruppuwa (octagon) of the Temple of the Tooth in Kandy in 1988 by Ranasinghe Premadasa and Gothabaya Rajapaksa's inauguration, just over three decades later, at the Ruvanveliseya, the iconic Buddhist temple built by the legendary Sinhala hero Dutugemunu. Each of these, together with the coupling of the offices of the president or prime minister with the portfolio for the protection of the Buddha Sasana, attest to the political perception of the indistinguishable nature of the interests of the Sinhala community and Buddhism in Sri Lanka. Every attempt at constitutional reform - even hints at reforming Article 9 of the Constitution which gives Buddhism the foremost place and of declaring Sri Lanka to be a secular state - has always been met with a storm of protest.

During and after the war, in the wake of allegations of war crimes and crimes against humanity by the overwhelmingly Sinhala Buddhist Sri Lankan government armed forces, there was also the belief that the Sinhala Buddhists were the victims of an international conspiracy fuelled by the Tamil diaspora (Rajapaksa 2011; Alagiah 2013; Athas 2009). This sustained and nurtured a strong sense of beleaguerment on the part of the Sinhala Buddhist majority (DeVotta 2016). In turn, this perception underpinned the victories of Mahinda Rakapaksa in the presidential elections of 2005 and 2010, and of his brother Gotabaya in the presidential election of 2019, as the only leaders who could resist Sinhala Buddhist victimization and protect the majority community.

Apart from a few monks, the vast majority of the Buddhist Sangha did not publicly state their aversion or condemnation of the war or the human rights violations it spawned, but argued instead that it was a just war against terrorism and the attempt to secede (see Zuhair 2016). ${ }^{2}$ Accordingly, following the military victory against the Tamil Tigers in May 2009, President Mahinda Rajapaksa was conferred the honour of Vishwa Keerti Sri Sinhaladhishwara (Universally Renowned Overlord of the Blessed Three Sinhala Regions), jointly by the Karaka Sangha Sabhas of the Malwatta and Asgiriya chapters of the Siyam Maha Nikaya. ${ }^{3}$ Accepting the honour, the President noted that he considered himself most fortunate to receive such a high accolade. He stated:

[T] he intention of the Maha Nayake Theras in conferring this honour was to ensure that the united Motherland would be preserved and safeguarded and I solemnly pledge before the Sacred Tooth Relic that I would never allow the bifurcation of the united Motherland. [The distinction was bestowed on me] for once again unifying my country under our National Lion flag. ${ }^{4}$

While the treatment of Tamils and Muslims after the war displayed no predisposition towards reconciliation - with continuing disappearances and 
violation of human rights, land grabs, the engagement, if not the domination, of the civilian economy in the north and the continued insistence on the innocence of the military in respect of allegations of war crimes and crimes against humanity - the affirmation of Sinhala Buddhist identity and its dominance continued apace. The Rajapaksa regime decided to update the historic Sinhala chronicle and epic poem about Sinhala rulers of the island written by the monk Mahanama in the late fifth to early sixth century, the Mahavāmsa, with six new chapters, three of which were to be devoted to the presidency of Mahinda Rajapaksa (Adaderana 2011).

While public commemorations by the families of Tamils who had died in the north and east of the country were banned on the grounds that they constituted celebrative tributes to the LTTE dead, the stationing of the security forces in the north and east, and the building of temples for their worship, was a key part of post-war "reconciliation" by the Rajapaksa regime (Fernando 2010). In June 2013, President Rajapaksa enshrined treasures in the Sandahiru Maha Seya (Triumphant Pagoda), one of nine new pagodas erected in each of the provinces of the island to commemorate the war victory and the heroic soldiers who gave their lives to achieve it. Tamil objections to the erection of Buddhist temples in the predominantly Hindu part of the country were not heeded. In response, Tamils constructed Hindu temples in the north on the grounds that the region was a predominantly Hindu part of the country and had to be appear as such.

Most recently, in June 2020, President Gotabaya Rajapaksa established a Presidential Task Force for Archaeological Heritage Management in the Eastern Province, headed by Archaeological Aryachakravarthi Venerable Ellawala Medhananda Thero, a Buddhist monk. ${ }^{5}$ The Task Force was notably mandated to identify sites of archaeological importance, restore identified sites and antiquities, identify the land that should be allocated for archaeological sites, preserve the cultural value of archaeological sites and promote the country's heritage. No Tamil or Muslim members were appointed to the Task Force in this multi-ethnic province. The assertion of the majoritarian ethno-religious identity was clear, with the agenda of creating the appropriate conditions for the marginalization of the minorities in the Eastern Province and thereby securing it, politically, for the regime. The Venerable Medhananda Thero stated that the goal of the Task Force was to examine and identify some 2,000 sites of Buddhist heritage.

\section{Conclusion}

Transitional justice is unlikely to be delivered anywhere in full in the wake of a military victory. In the Sri Lankan case, the question arises as to whether any significant process of transitional justice can be instituted in the face of the majority community's deep and solid resistance to accountability in particular. While the Mahinda Rajapaksa presidency affirmed that the military victory should be followed by a political settlement of the conflict, it became 
clear that the regime believed otherwise and looked to economic development at best as the substitute for such a settlement. The process of transitional justice was set aside. At the time of writing, following the victory of Gotabaya Rajapaksa in the 2019 presidential election, key positions in government were staffed by serving and former armed forces personnel, some of whom had allegations of war crimes against them. Those measures of transitional justice that had been instituted were largely a consequence of international pressure from the UNHRC and, apart from the period 2015-19, served the purpose of buying time rather than a making a firm commitment to transitional justice.

Buddhism provides an unimpeachable and otherworldly justification for the privileging of Sinhala Buddhist identity in Sri Lanka. This, however, belies some very secular concerns and fears that lead the majority community to espouse it so stridently. In effect, Sinhala Buddhist majoritarianism is also a reaction and backlash against globalization, about the loosening of identities and therefore of the threat to the distinctiveness of a community. It provides a rationale and cover for holding onto economic power and resources.

The new post-war conflict with the Muslim community, prior to the Easter Sunday carnage of 2019, was largely targeted against its economic power and resources. It was mainly Muslim-owned businesses that were targeted, and the propaganda too was aimed at ensuring a boycott of Muslim business establishments. The Muslim stake in the retail trade was at the heart of the attacks about their distinctive cultural practices and of the hysteria about reproductive rates, which were alleged to be the means to replace the majority Sinhala Buddhist community with a Muslim one. It was not a fear of secession, but rather of the usurpation of the majority community's position at the apex of the power hierarchy in the country.

As for the government's annual commemorations of the military war victory, they serve to demonstrate the apex position of Sinhala Buddhist identity within the power hierarchy of the country. Everything else is to follow from it and everything else is possible only to the extent that this apex position is not disturbed but continues to be enshrined and acknowledged. As Suren Raghavan, a scholar of the politics of Sinhala Buddhism, a former governor of the Northern Province and an SLPP member of parliament points out:

It is a sociological and psychological fact that Sinhalas, especially the Sangha, are looking for a point of pride after three decades of humiliation under a homegrown Tamil-armed rebellion led by a school dropout. The LTTE not only came close to dividing the state, it was nearly successful in permanently dismantling the majoritarian hegemonic mindset of the Sinhala polity. Sinhalas as a regional and global minority take pride in their steadfast resilient to hold Lanka as a Sinhala majority Buddhist state even after some 450 years of harsh European 
colonization. What the LTTE - with its terror politics - tried to change was not merely the unitary nature of Lanka but also the historicized Sinhala Buddhist ethnoreligious national pride. Sangha as direct recipients and beneficiaries in overcoming such ontological insecurities have become the natural champions of a new order that will not only wipe away such shame but also re-establish overarching control. ${ }^{6}$

What the military victory has done, with its dominant Sinhala Buddhist idiom of celebration and commemoration, is to openly challenge and jettison the idea of Sri Lanka as a plural, multi-ethnic and religious society founded on the notion of "unity in diversity". It has now been replaced by the idea of a majoritarian society of Sinhala Buddhist primacy, with all the authoritarian impulses and attitudes that it entails to secure and consolidate this idea.

\section{Notes}

1 Following the war, only in the latter years of the Yahapalanaya (Good Governance) government in power from 2015-19 was the national anthem sung in both official languages, Sinhala and Tamil.

2 The scholarly monk Ven Walpola Rahula wrote with reference to the battle between Sinhala Prince Dutugemunu and the Tamil Chola King Elara: "From this time the patriotism and the religion of the Sinhalese became inseparably linked ... and assumed such overpowering proportions that both bhikkus and layman considered that even killing people in order to liberate the religion and the country was not a heinous crime." (Rahula Walpola 1946 and quoted in Zuhair 2016).

3 The title translates as the Universally Renowned Overlord of the Blessed Three Sinhala Regions - the latter regions being Ruhuna, Pihita and Maya, each of which was ruled by a separate king at the time of the Portuguese invasion in 1505 . The Malwatte and Asgiriya chapters are the two main "chapters" of the Sangha or priesthood. The monasteries of the two main chapters have enjoyed the right, upheld by the British colonial government, to make appointments to the major Budddhist centres in the country.

4 Quoted in the Daily News, on Monday 25 May 2009 and in the Asian Tribune, on Sunday 24 May 2009.

5 Suren Raghavan, "Sri Lanka: Towards a militant Sangha state", 23 November 2013, www.colombotelegraph.com/index.php/sri-lanka-towards-a-militant-sangha -state.

6 Raghavan, Suren. "Sri Lanka: Towards a militant Sangha state". Colombo Telegraph, 23 November 2013, www.colombotelegraph.com/index.php/sri-lanka-towa rds-a-militant-sangha-state.

\section{References}

Adaderana. "Three chapters on President in Mahavamsa: Report". April 6, 2011, www.adaderana.lk/news.php?nid=12692.

Alagiah, George. "Sri Lanka's retreat into language of conspiracy". BBC News Colombo, 15 November 2013, bbc.com/news/world-asia-24951955.

Anketell, Niran. "Hijacked Justice? Truth and reconciliation in Sri Lanka". Open Democracy, 3 December 2013, www.opendemocracy.net. 
Athas, Iqbal. "Sri Lanka president makes conspiracy claims". CNN World, 9 January 2009, edition.cnn.com/2009/WORLD/asiapcf/01/09/sri.lanka.civil.war/index.html.

Balachandran, P.K. "Northern Sri Lankan Governor defends building Buddhist temples”. 18 August 2016, newindianexpress.com/world/2016/aug/18/North-SriLa nkan-Governor-defends-building-Buddhist-temples-1510667.html.

Centre for Policy Alternatives. "A Critique of Promises Made and Present Trends". Colombo, Centre for Policy Alternatives, forthcoming.

Centre for Policy Alternatives. Confronting accountability for hate speech in Sri Lanka: A critique of the legal framework. Colombo, Centre for Policy Alternatives, September 2018.

Centre for Policy Alternatives. "INFOGRAPHICS: Military Presence in the North of Sri Lanka”. Colombo, Centre for Policy Alternatives18 September 2014, www.cpa lanka.org/infographic-military-presence-in-the-north-of-srilanka/.

Centre for Policy Alternatives, "Practical steps to meaningful reconciliation", Colombo, Centre for Policy Alternatives, 17 February 2012, www.cpalanka.org/pra ctical-steps-tomeaningful-reconciliation/.

Centre for Policy Alternatives. Saving Sunil: A study of dangerous speech around Facebook dedicated to Sgt Sunil Rathnayake. Colombo, Centre for Policy Alternatives, October 2015.

De Silva, Roshan Wijeyeratne. "Republican constitutionalism and Sinhalese Buddhist nationalism in Sri Lanka: Toward an ontological account of the Sri Lankan state". The Sri Lankan Republic at 40: Reflections on constitutional history, theory and practice, edited by Asanga Welikala. Colombo, Centre for Policy Alternatives, 2012.

DeVotta, Neil. "Engaging Sinhalese Buddhist majoritarianism and countering religious animus in Sri Lanka: Recommendations for the incoming u.s administration”. The Review of Faith \& International Affairs, vol. 14, no. 2, 2016, pp. 76-85, doi:10.1080/15570274.2016.1184440.

Dissanayake, Uvin. Technocratic Populism and the Pandemic State: Performative Governance in Post-Covid Sri Lanka. Colombo, Centre for Policy Alternatives, November 2020.

Fernando, Jude Lal. "War by other means: Expansion of Sinhala Buddhism into Tamil region in 'post war' Ilam". Buddhism among Tamils in Tamilakam and İlam. Part 3: Extension and Conclusions, edited by Peter Schalk and Astrid van Nahl, Uppsala, Acta Universitatis Upsaliensis, 2013, pp. 175-238.

Fernando, Jude Lal. "Remembering Mu'l'livaaykaal in proper context". 15 May 2017, tamilnet.com/aut.html artid $=38678 \&$ catid $=79$.

Fernando, Ruki. "Celebrating war victory and banning commemoration of dead victims: This is a homegrown and indigeneous reconciliation and freedom in Sri Lanka". Groundviews, 18 June 2010, https://groundviews.org.

Gammanpila, Udaya. "The constitutional form of the First Republic: The Sinhala Buddhist perspective: an interview". The Sri Lankan Republic at 40: Reflections on constitutional history, theory and practice, edited by Asanga Welikala, Colombo, Centre for Policy Alternatives, 2012.

Governeur, Cédric. "An uncomfortable peace in Sri Lanka: The time of triumphalism”. The Sri Lanka Campaign, 17 April 2010, www.srilankacampaign.org/a n-uncomfortable-peace-in-sri-lanka-the-time-of-triumphalism.

Groundviews. "The official report of the LLRC". Groundviews, 16 December 2011, www.groundviews.org. 
Gunasekera, Tisaranee. "Cult and its heretics". Colombo Telegraph, 24 January 2021, www.colombotelegraph.com/index.php/cult-and-its-heretics.

Gunasekara, Tisaranee. "Gotabhaya Rajapaksa and Bala Sena”. Colombo Telegraph, 14 March 2013, www.colombotelegraph.com/index.php/gotabhaya-rajapaksa-and-his-ba lasena.

Human Rights Watch. "Open wounds and mounting dangers: Blocking accountability for grave abuses in Sri Lanka". Human Rights Watch, 1 February 2021, www.ecoi.net/en/file/local/2044618/srilank0221web.pdf.

Hume, Tim. "Fascists' in saffron robes? The rise of Sri Lanka's Buddhist ultranationalists". CCN World, 17 July 2014, https://edition.cnn.com/2014/07/17/ world/asia/sri-lanka-bodu-bala-sena-profile/index.html.

Kent, Lia, "No Space for Memory?: Memorials, Monuments and the Residues of the War in Sri Lanka's North". Arena Quarterly, 29 May 2020, arena.org.au/no-spa ce-for-memory/.

International Crisis Group. "A dangerous sea-change in Sri Lanka”. International Crisis Group, 29 January 2020, crisisgroup.org/asia/southasia/srilanka/dangerousseachange-sri-lanka.

International Crisis Group. Sri Lanka’s Transition to Nowhere. Asia Report No. 286, International Crisis Group, 16 May 2017, https://d2071andvip0wj.cloudfront.net/ 286-sri-lanka-s-transition-to-nowhere.pdf. Accessed 27 February 2021.

Jayasuriya, Ranga. "Cyril Ramaphosa: What's he doing out here in Sri Lanka?". Ceylon Today, Sri Lanka Brief, 16 July 2014, www.srilankabrief.org.

Jayasuriya, Ranga. Sri Lanka Report. Geneva, Office of the High Commissioner of Human Rights, 27 January 2021.

Jayawickreme, Eranda, Nuwan Jayawickreme, and Elsie Miller. "Triumphalism, fear and humiliation: The psychological legacy of Sri Lanka's civil war". Dynamics of Asymmetric Conflict, 2010, vol. 3, no. 3, pp. 208-222, doi:10.1080/17467586.2010.531031.

Peiris, Kamalika. "Sinhala triumphalism". Lankaweb, 10 July 2018, www.lankaweb. com.

Perera, Melani Mkaanel, "Military building Buddhist temples against local wishes in northern Sri Lanka”. 6 September 2015, asianews.it/news-en/Military-buildingBuddhist -temples- against-local-wishes-in-northern-Sri Lanka-34463.html.

Raghavan, Suren. "Sri Lanka: Towards a militant Sangha state". Colombo Telegraph, 23 November 2013, www.colombotelegraph.com/index.php/sri-lanka-towards-a -militant-sangha-state.

Rajapaksa, Gotabaya. "Address to the nation". Colombo, Government of Sri Lanka, 18 November 2020, www.news.lk/news/politics/item/31072-full-text-of-the-addres s-to-the-nation-by-his-excellency-thepresdent-gotabaya-rajapaksa.

Rajapaksa, Mahinda. "Defeating domestic and foreign conspiracies against Sri Lanka". Colombo Telegraph, 28 June 2020, www.colombotelegraph.com/index. $\mathrm{php} /$ defeating-domestic-and-foreign-conspiracies-against-srilanka.

Rajapaksa, Mahinda. "Sri Lanka President defends military role". BBC, www.bbc. com/news/world/south asia-13570810, 22 May 2011.

Schonthal, Benjamin, and Matthew J. Walton. "The new Buddhist nationalisms: Symmetries and specificities in Sri Lanka and Myanmar". Contemporary Buddhism: An Interdisciplinary Journal, 2016, vol 17, no. 1, pp. 81-115, doi:10.1080/ 14639947.2016.1162419.

Schonthal, Benjamin, and Asanga Welikala. "Buddhism and the regulation of religion in the new constitution: Parliamentary debates, present challenges and future 
options". Working Papers on Constitutional Reform No 3, Colombo, Centre for Policy Alternatives, July 2016.

South China Morning Post. "Radical monk seeks alliance with Buddhists in Sri Lanka". South China Morning Post, 30 September 2014, www.scmp.com/news/a sia/article/1604065/radical-myanmar-monk-seeks-alliance-buddhists-sri-lanka.

Srilal, Ranga. "Radical Myanmar monk joins hands with Sri Lankan Buddhists", Reuters, 29 September 2014, www.reuters.com/article/us-sri-lanka-buddhism-mya nmar-idUSKCN0HO0GD20140929.

Walpola, Rahula. The heritage of the Bhikkus: The Buddhist tradition of service. New York, Grove/Atlantic, 1946/2007.

Wickremesinhe, Roshini, and Sanjana Hattotuwa. Voting in hate: A study of hate speech on Facebook surrounding Sri Lanka's parliamentary elections of 2015. Colombo, Centre for Policy Alternatives, March 2016.

Zuhair, Ayesha. Dynamics of Sinhala-Buddhist ethno-nationalism in post-war Sri Lanka". Colombo, Centre for Policy Alternatives, April 2016. 